EXTENDED REPORT

\title{
A longitudinal study on an autoimmune murine model of ankylosing spondylitis
}

\author{
T Bárdos, Z Szabó, M Czipri, C Vermes, M Tunyogi-Csapó, R M Urban, K Mikecz, \\ T T Glant
}

See end of article for authors' affiliations

Correspondence to:

Dr T T Glant, Department

of Orthopedic Surgery,

Rush University Medical

Center, Cohn Research

Building, Room 708,

1735 W Harrison Street

Chicago, IL 60612, USA;

tglant@rush.edu

Accepted

21 November 2004

Published Online First

7 January 2005

Background: Proteoglycan aggrecan (PG)-induced arthritis (PGIA) is the only systemic autoimmune murine model which affects the axial skeleton, but no studies have been performed characterising the progression of spine involvement.

Objectives: To follow pathological events in experimental spondylitis, and underline its clinical, radiographic, and histological similarities to human ankylosing spondylitis (AS); and to determine whether the spondyloarthropathy is a shared phenomenon with PGIA, or an "independent" disease.

Methods: Arthritis/spondylitis susceptible BALB/c and resistant DBA/2 mice, and their F1 and F2 hybrids were immunised with cartilage PG, and radiographic and histological studies were performed before onset and weekly during the progression of spondylitis.

Results: About 70\% of the PG immunised BALB/c mice develop spondyloarthropathy (proteoglycaninduced spondylitis (PGISp), and the progression of the disease is very similar to human AS. It begins with inflammation in the sacroiliac joints and with enthesitis, and then progresses upwards, affecting multiple intervertebral disks. In F2 hybrids of arthritis/spondylitis susceptible BALB/c and resistant DBA/2 mice the incidence of arthritis was $43.5 \%$, whereas the incidence of spondylitis was $>60 \%$. Some arthritic F2 hybrid mice had no spondylitis, whereas others developed spondylitis in the absence of peripheral arthritis.

Conclusions: The PGISp model provides a valuable tool for studying autoimmune reactions in spondylitis, and identifying genetic loci associated with spondyloarthropathy.

A nkylosing spondylitis (AS) is a chronic inflammatory autoimmune disease of the axial skeleton, and considered to be a "prototype" of the spondyloarthropathies (SpAs). AS frequently shows familial aggregation with male preponderance, and the association of AS with the human leucocyte antigen (HLA)-B27 as strong evidence of its autoimmune aetiology, was first described more than 30 years ago. ${ }^{1}$ The combination of HLA-B27 with other HLA alleles (HLA-B60 and HLA-B35) was found to increase the genetic predisposition up to sixfold, ${ }^{23}$ and genome-wide screening studies suggested that AS has a polygenic character. $^{45}$ Despite intensive research, the pathological mechanism of AS is unknown. Studies on putative autoantigens implicated molecular mimicry, represented by Klebsiella antigens, ${ }^{6-9}$ Yersinia antigens, ${ }^{10-12}$ self recognised HLAB27, ${ }^{11}{ }^{13} 14$ or epitopes in the cartilage proteoglycan aggrecan $(\mathrm{PG})^{15-19}$ in AS.

Animal models are invaluable aids in the research of human autoimmune diseases, and there are only a few systemic animal models, mostly in genetically altered rodents, which involve intervertebral disk (IVD) pathology ${ }^{20-27}$ Among the rodent models of the SpAs, immunisation of susceptible mice (BALB/c and some $\mathrm{C} 3 \mathrm{H}$ substrains) with human cartilage $\mathrm{PG}^{28-30}$ or with the $\mathrm{Gl}$ domain of aggrecan or versican, ${ }^{31}{ }^{32}$ induces progressive polyarthritis which is frequently associated with spondylitis resembling human AS. Although spine involvement in PG-induced arthritis (PGIA) has been known since the murine model was first described, ${ }^{28} 33$ no systemic study has been performed to determine whether it is only a concomitant phenomenon of peripheral arthritis, or whether arthritis and spondylitis represent two different diseases; although both are induced by immunisation with cartilage PG. Here we describe a longitudinal study on the spine during the progression of PGIA in BALB/C mice. We also show a clear divergence of the two models (arthritis and spondylitis) in F2 hybrids of arthritis susceptible (BALB/c) and arthritis resistant (DBA/2) strains of mice.

\section{MATERIALS AND METHODS \\ Antigens, animals, experimental groups, and immunisation}

The use of human cartilage from joint replacement operations for antigen isolation was approved by the Institutional Review Board, and all animal experiments were approved by the Institutional Animal Care and Use Committee. Human cartilage PG was used for immunisation of 24-26 week old female BALB/c mice purchased from the National Cancer Institute (NCI, Kingston Colony, NY). Preparation of cartilage PG was carried out as described earlier. ${ }^{3435}$ As a standard method, ${ }^{30} 3435$ the first antigen injection (100 $\mu$ g PG protein) was given in complete Freund's adjuvant (Difco, Detroit, MI), and the same doses of antigen were injected as second and third boosts in incomplete Freund's adjuvant on weeks 3 and $6(\mathrm{n}=210)$. Control female BALB/c mice matched for age were either not immunised $(n=75)$ or immunised with ovalbumin, a non-cartilage-related antigen in adjuvant $(n=75)$. A small group of PG immunised male mice $(\mathrm{n}=12)$ was used as a positive control, and ovalbumin plus adjuvant injected BALB/C male mice $(n=8)$ as a negative control group, and all were killed at the end of the experiments at week 36 (fig 1).

In a second set of experiments, arthritis and spondylitis susceptible BALB/C female mice 28303334 were mated with arthritis resistant $\mathrm{DBA} / 2$ male mice and the resulting $\mathrm{F} 1$ offspring were mated to generate F2 hybrids. These F1

Abbreviations: AS, ankylosing spondylitis; IVD, intervertebral disk; PG, proteoglycan aggrecan; PGIA, PG-induced arthritis; PGISp, PG-induced spondylitis; SpA, spondyloarthropathy 


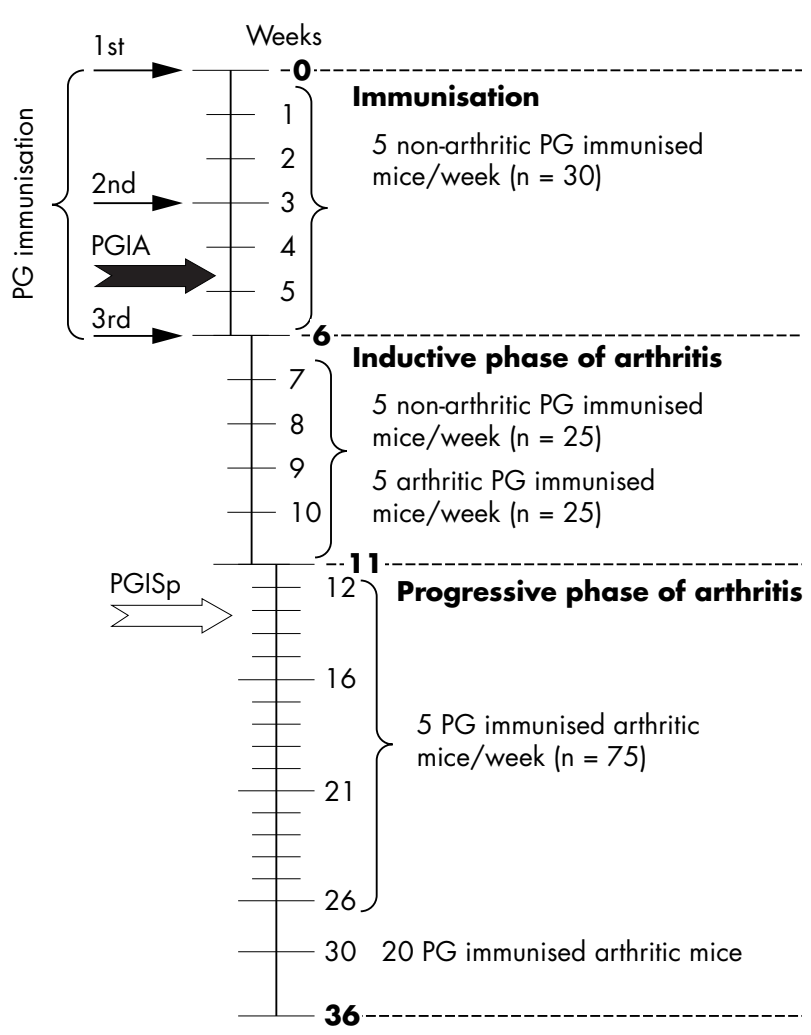

35 female and 12 male PG immunised arthritic $B A L B / c$ mice

Figure 1 Time course of immunisation, number of animals killed and analysed weekly, and the time of onset of arthritis in peripheral joints (PGIA; thick black arrow) and spondylitis (PGISp; thick white arrow). A total of 210 female BALB/c mice were immunised with human cartilage PG in the first experimental group, and five killed weekly.

(36 female mice and 12 male mice) and all F2 hybrids (106 female mice and 117 male mice) of $\mathrm{BALB} / \mathrm{c} \times \mathrm{DBA} / 2$ intercrosses were also immunised with cartilage $P G$ as described above. ${ }^{29} 3436$

\section{Clinical and histological assessments of arthritis and spondylitis}

Immunised BALB/C mice were examined twice a week for clinical symptoms of arthritis. A standard scoring system, based upon swelling and redness of each paw (a maximum score of 4 for each paw) was used for the assessment of arthritis..$^{34} 35$ During the first 6 weeks of immunisation (until the third injection), we killed five immunised mice every week. During the next 5 weeks, as arthritic mice became available (fig 1; inductive phase of arthritis), we killed five arthritic and five as yet non-arthritic mice each week (fig 1). From week 12 (that is, 6 weeks after the third injection), when eventually all PG aggrecan immunised BALB/c mice were arthritic, except for three female mice (table 1), we killed five mice weekly until week 26 , and then 20 arthritic mice were killed at week 30 . The remaining 32 arthritic and three non-arthritic PG immunised female mice, and all male mice, were killed on the last day (week 36) of the experimental period (fig 1).

In the second set of experiments, PG immunised BALB/C $(\mathrm{n}=81), \mathrm{DBA} / 2(\mathrm{n}=48)$, and their F1 $(\mathrm{n}=48)$ and $\mathrm{F} 2$ $(n=223)$ hybrid offspring were scored weekly, and onset and severity of arthritis were recorded as described above for $\mathrm{BALB} / \mathrm{c}$ mice. Animals were killed on week 30 and disease onset and severity were correlated with the final histological score of the spine.

Serial sections were stained with haematoxylin-eosin, safranin O-fast green, and picrosirius red. ${ }^{37} 38$ Spines of control, and age matched PG immunised arthritic BALB/C mice were stained with alizarin red and alcian blue for gross pathological examination, as described elsewhere. ${ }^{39}$

A histology scoring system was established for the severity of spine involvement: score 1, enthesitis, inflammatory cell accumulation around the IVD and/or infiltration of the annulus fibrosus; score $2,<50 \%$ absorption/erosion of the IVD; score 3, essentially complete resorption $(>50 \%)$ of the IVD; score 4, cartilaginous/bony ankylosis. A minimum of $18-$ 22 IVDs (from the distal cervical to the lumbar regions) of each control and immunised mouse was scored. Finally, the spondylitis score of each animal was calculated by dividing the total score (all IVD scores) by the number of IVDs examined histologically. Autoimmune reactions (antibody production and $\mathrm{T}$ cell responses) to immunising human and mouse (self) PGs were determined as described previously. ${ }^{28} 343540$

\section{RESULTS \\ Development of peripheral arthritis, and PG-specific antibody and $\mathrm{T}$ cell responses}

As described earlier ${ }^{28} 3034$ and above (experimental groups), most of the PG immunised BALB/c mice developed peripheral arthritis between days 7 and 14 after the third antigen injection (table 1). All arthritic mice showed strong humoral and cellular immune responses to $\mathrm{PG}$, as described in detail in our earlier papers. ${ }^{30}$ In this respect, we found no differences between mice with and without spine involvement, and no correlation between the severity of spondylitis and PG-specific antibody levels. In a similar way to that described above for antibody responses, T cell reactions in PG immunised BALB/c mice with and without spondylitis were highly comparable, and neither PG-specific antibodies nor $\mathrm{T}$ cell responses were detected in non-immunised or ovalbumin/adjuvant immunised mice.

Table 1 Incidence of arthritis and spondylitis in cartilage PG immunised mice

\begin{tabular}{|c|c|c|c|c|c|c|c|c|}
\hline & \multicolumn{8}{|c|}{ Week of the experiment } \\
\hline & 0 & 6 & 11 & 16 & 20 & 26 & 30 & 36 \\
\hline $\begin{array}{l}\text { Weeks after the 3rd PG immunisation } \\
\text { Incidence of peripheral arthritis* }\end{array}$ & $\begin{array}{l}-6 \\
0 / 210 \\
(0 \%)\end{array}$ & $\begin{array}{l}0 \\
8 / 180 \\
(4 \%)\end{array}$ & $\begin{array}{l}5 \dagger \\
127 / 130 \dagger \\
(98 \%)\end{array}$ & $\begin{array}{l}10 \\
107 / 110\end{array}$ & $\begin{array}{l}14 \\
82 / 85\end{array}$ & $\begin{array}{l}20 \\
52 / 55\end{array}$ & $\begin{array}{l}24 \\
20 / 20\end{array}$ & $\begin{array}{l}30 \\
44 / 47\end{array}$ \\
\hline Incidence of spondylitis $\ddagger$ & ND & $\begin{array}{l}0 / 30 \\
(0 \%)\end{array}$ & $\begin{array}{l}0 / 50 \\
10 \%)\end{array}$ & $\begin{array}{l}13 / 25 \\
(52 \%)\end{array}$ & $\begin{array}{l}16 / 25 \\
(64 \%)\end{array}$ & $\begin{array}{l}18 / 25 \\
(72 \%)\end{array}$ & $\begin{array}{l}14 / 20 \\
(70 \%)\end{array}$ & $\begin{array}{l}34 / 47 \\
(72 \%)\end{array}$ \\
\hline
\end{tabular}

*Incidence is expressed as the number of affected/total BALB/c mice (results are also shown as \% in parentheses). The last column includes results of the 12 positive control male mice (PGISp incidence 75\%), whereas all other animals were female BALB/c mice; tby week 5 after the third PG injection, only three PG immunised mice remained non-arthritic, and these animals were followed up until the end of the experiment. Two of these three non-arthritic BALB/c mice developed spondylitis; łcalculation is based upon histological analysis of the spine, and positive/total number of killed animals (\%) is shown. 

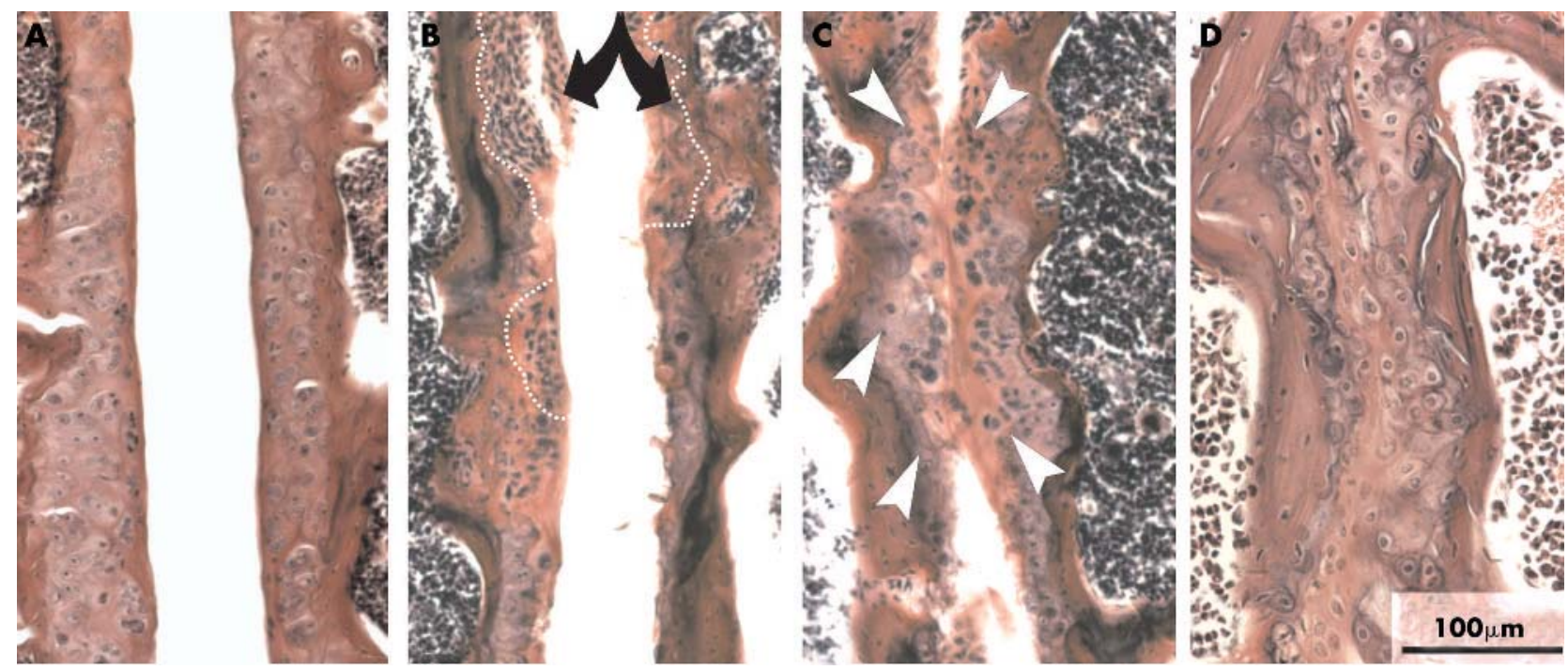

Figure 2 Inflammation of the sacroiliac joints and progression of ankylosis in PG immunised BALB/c mice with spondylitis. The normal sacroiliac joint (A), which is first eroded by a synovial pannus-like hyperproliferative tissue (black arrows) at the articular surfaces indicated with dotted lines in (B), as early as 4-6 weeks after the onset of arthritis in the peripheral joints. This was followed shortly by massive proliferation of chondrocyte-like cells (white arrowheads in (C), which formed a junction of chondrophytes, resulting in complete ankylosis of the sacroiliac joint (D). The tissue sections were stained with haematoxylin and eosin.

\section{Histological assessment of spine involvement in PG immunised BALB/c mice}

Histological analysis showed axial involvement as early as week 8 after the third PG injection (data not shown). The disease affected only the PG immunised mice, and abnormalities could not be detected in any of the control animals. Cartilage surface erosions were found first in the sacroiliac joints (fig 2B); IVDs of the proximal tail became affected simultaneously with, or shortly after, the development of inflammation in the sacroiliac joint. During the course of the disease, first the lumbar, and later the proximal, thoracic and distal cervical segments became involved, but not all IVDs were equally affected at a particular time. The fibrocartilaginous articular surface of the sacroiliac joints became eroded (fig 2B), which was followed by a focal (fig 2C) and then more extensive (fig 2D) chondrocyte proliferation. This reactive cell proliferation gave rise to chondrophyte-like tissue; the sacroiliac joint was completely ankylosed within 1-2 months after the first $x$ ray examination (not shown) and histological abnormalities could be seen (fig 2D).

In the acute phase of spondylitis, strong mononuclear infiltration appeared, ${ }^{28-30}$ leading to destabilisation of the IVD. The damaged or resorbed annulus fibrosus allowed the nucleus pulposus to protrude in a ventral direction. The protruding IVD or the growing osteophytes frequently caused compression of the spinal cord, particularly at the lower cervical regions (fig 3D).

To study the changes in the extracellular matrix and its components, sections were stained with safranin $\mathrm{O}$ to assess the PG content (figs 3B and 3E), and picrosirius red staining was used to determine the orientation of the collagen fibres by polarisation microscopy (figs $3 \mathrm{C}$ and $3 \mathrm{~F}$ ). Safranin $\mathrm{O}$ staining disclosed that, in addition to the growth plate and end plate of the vertebral body, the nucleus pulposus and the annulus fibrosus also contained large amounts of PG (fig 3B). PG was lost from end plates, but large chondrophytes, and later osteophytes, grew at connecting adjacent vertebral bodies (fig 3E). Polarisation microscopy showed normal lamellar orientation of the collagen fibres in the annulus fibrosus and end plate in normal IVDs (fig 3C); an orientation which was lost in affected IVDs (fig 3F).

\section{Macroscopic analysis of spondylitic spines}

For macroscopic examination, spines were stained with alizarin red and alcian blue (fig 4). This staining shows more details of the cartilaginous and bony components of the deformed spine regions. In contrast with the normal disk, where the growth plates and end plates of the vertebral bodies appeared as sharp solid lines (fig 4A), the contours of these cartilaginous tissues became diffuse owing to chondrophyte formation (fig 4B). Progression of spondylitis was seen in each animal that developed spondylitis: the disk space disappeared and a chondrophyte/osteophyte, fusing the neighbouring vertebral bodies, replaced the original IVD (fig 4C).

\section{Analysis of peripheral arthritis and spondylitis in F2(BALB /c $\times$ DBA/2) hybrid mice}

As described above, three PG immunised BALB/c female mice did not develop PGIA, but two of the three showed SpA at the end of the experiment (table 1). Therefore, we assume that SpA develops independently of arthritis in PG immunised $\mathrm{BALB} / \mathrm{c}$ mice. To confirm this hypothesis and separate overlapping clinical, histopathological, and laboratory measures of the two diseases, we immunised $223 \mathrm{~F} 2(\mathrm{BALB} / \mathrm{C} \times$ $\mathrm{DBA} / 2$ ) hybrids, and their parents. All mice (BALB/c, DBA/2, F1 and F2 hybrids) were killed on week 30 of immunisation, as the development of PG-induced spondylitis (PGISp) achieved a constant $(\sim 70 \%)$ level by week 26 of immunisation (table 1). Figure 5A shows the major characteristics and distribution of peripheral arthritis and spondylitis in these experimental groups. About $40 \%$ of the PG immunised F2 $(\mathrm{BALB} / \mathrm{C} \times \mathrm{DBA} / 2)$ mice developed PGIA, but unexpectedly, over $60 \%$ had spondylitis. Most of the arthritic mice had spondylitis (85/97), and 52/223 (23.3\%) PG immunised F2 hybrids had spondylitis without joint inflammation (fig 5A; right panel).

In this second set of experiments, 81 (63 female and 18 male) BALB/c mice developed PGIA (mean (SD) arthritis score $11.6(2.4)$ ), which was associated with PGISp (mean (SD) spondylitis score of affected animals $1.45(0.62))$ in 57 $(70 \%)$ animals. 

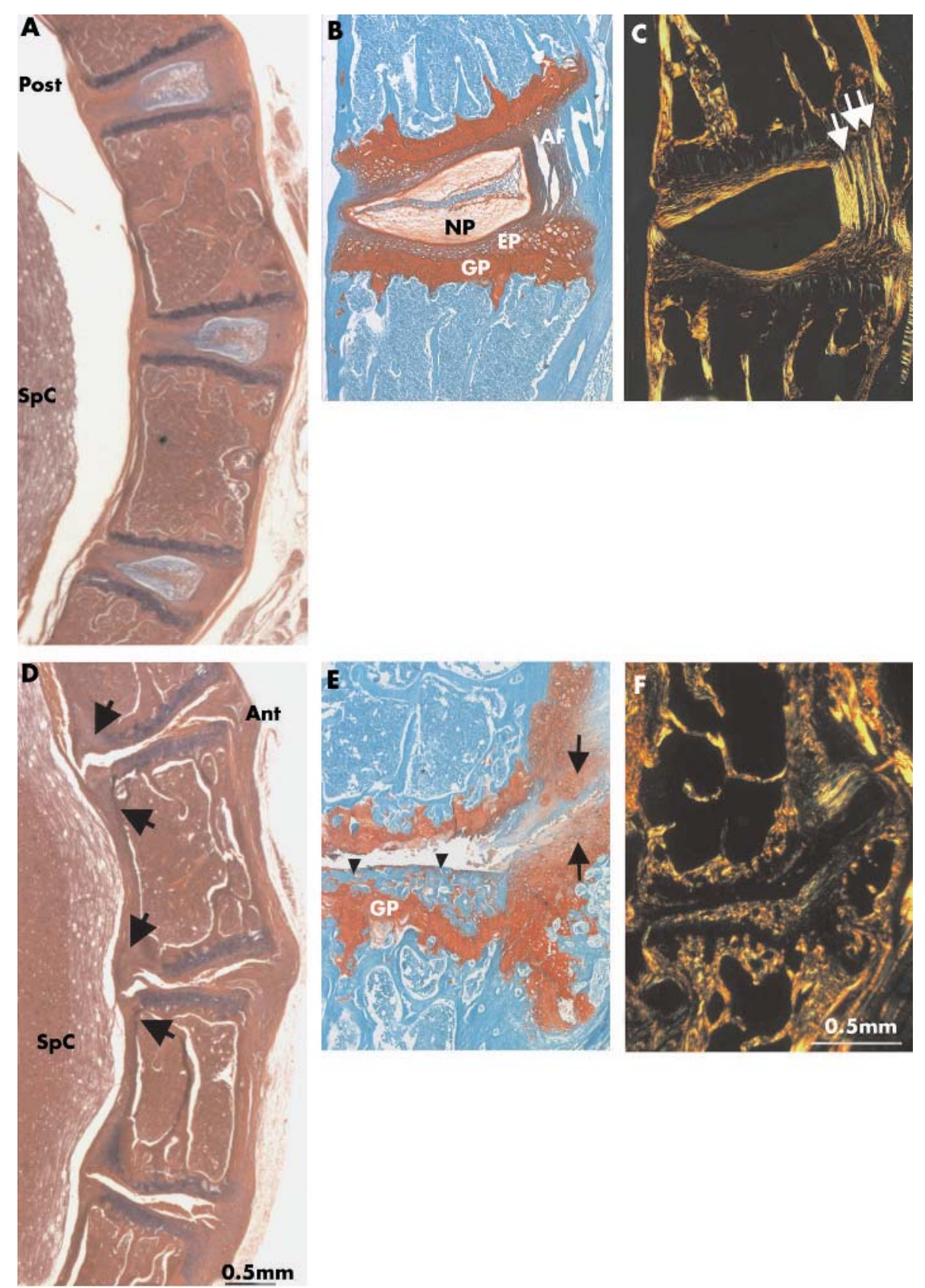

Figure 3 Cervical spine segments in $(A, B, C)$ normal mice and in $(D, E, F)$ mice afflicted with spondylitis. The affected disks are shown with the ankylosing osteophytes (black arrows: IVD C4/C5), which protrude and compress the spinal cord (SpC) (D). Massive enthesitis develops with a pannus-like tissue eroding the rest of the IVD at the ventral side of the spine. Safranin $O /$ fast green staining (B, E) demonstrates the PG content (red) in the growth plate (GP), in the cartilaginous end plate (EP), and, less intensively, in the annulus fibrosus (AF) and nucleus pulposus (NP) of the normal (B) or spondylitic (E) spine. In the affected spine $(E)$ the annulus fibrosus and the nucleus pulposus have been completely resorbed and the end plate (black arrowheads) is essentially absent (E). The neighbouring vertebral bodies are connected by chondrophytes (black arrows), which ankylose the spine. Polarisation microscopy of sections stained with picrosirius red (panels C and F) indicates that the regularity of collagen fibres, due to parallel orientation in the normal annulus fibrosus (C; white arrows), is completely lost in the annulus fibrosus of the disk affected by inflammation (F).

\section{DISCUSSION}

Normal IVD is a complex fibrocartilaginous structure containing poorly defined chondrocyte-like and fibroblastlike cells that can survive in a relatively avascular environment. The extracellular matrix of the IVD contains two major groups of macromolecules: collagens and proteoglycans. Whereas the nucleus pulposus contains almost uniformly aggrecan and type II collagen, the annulus fibrosus is formed mostly by type I collagen fibrils embedded in aggrecan and versican. ${ }^{41}$ The insertion site of the ligaments into the cortical bone-that is, the enthesis, also contains proteoglycan, mostly versican, ${ }^{42}$ which might be degraded in IVDs undergoing degenerative processes..$^{43}$

The core protein of human cartilage (and nucleus pulposus) PG comprises more than 2300 amino acids, and contains $20-27 \mathrm{~T}$ cell epitope $\mathrm{s}^{30}$ presented to $\mathrm{T}$ cells by various major histocompatibility complexes of antigen presenting cells. ${ }^{45}$ Most of these epitopes, however, are in a "cryptic" position - that is, masked by glucosaminoglycan side chains. A few T cell epitopes of human PG have been characterised as dominant/arthritogenic, and owing to the high sequence homology between human and mouse PGs ${ }^{46}{ }^{47}$ immunisation of susceptible $\mathrm{BALB} / \mathrm{c}$ and $\mathrm{C} 3 \mathrm{H}$ mice with human $\mathrm{PG}$ provokes autoimmune responses to mouse (self) PGs, which then induce arthritis and spondylitis. ${ }^{28-30} 34$

Spondylodiscitis (a robust form of inflammation affecting the entire IVD) occurs in $15 \%$ of patients with $\mathrm{AS}^{48}$ but the incidence is greater (up to $60 \%$ ) when diagnosed by magnetic resonance imaging. ${ }^{49}$ The primary site of the inflammation in AS, however, is still debated; it is proposed to be in the subchondrium $^{49}$ or in the synovium (sacroiliac joint) close to the entheses. ${ }^{50}$

To date, spontaneous or experimentally induced disk degeneration has been reported only in a few animal models. ${ }^{20-22} 24262751$ Autoimmune mechanisms are thought to play a part only in HLA-B27 transgenic rodents ${ }^{23} 2552$ and 

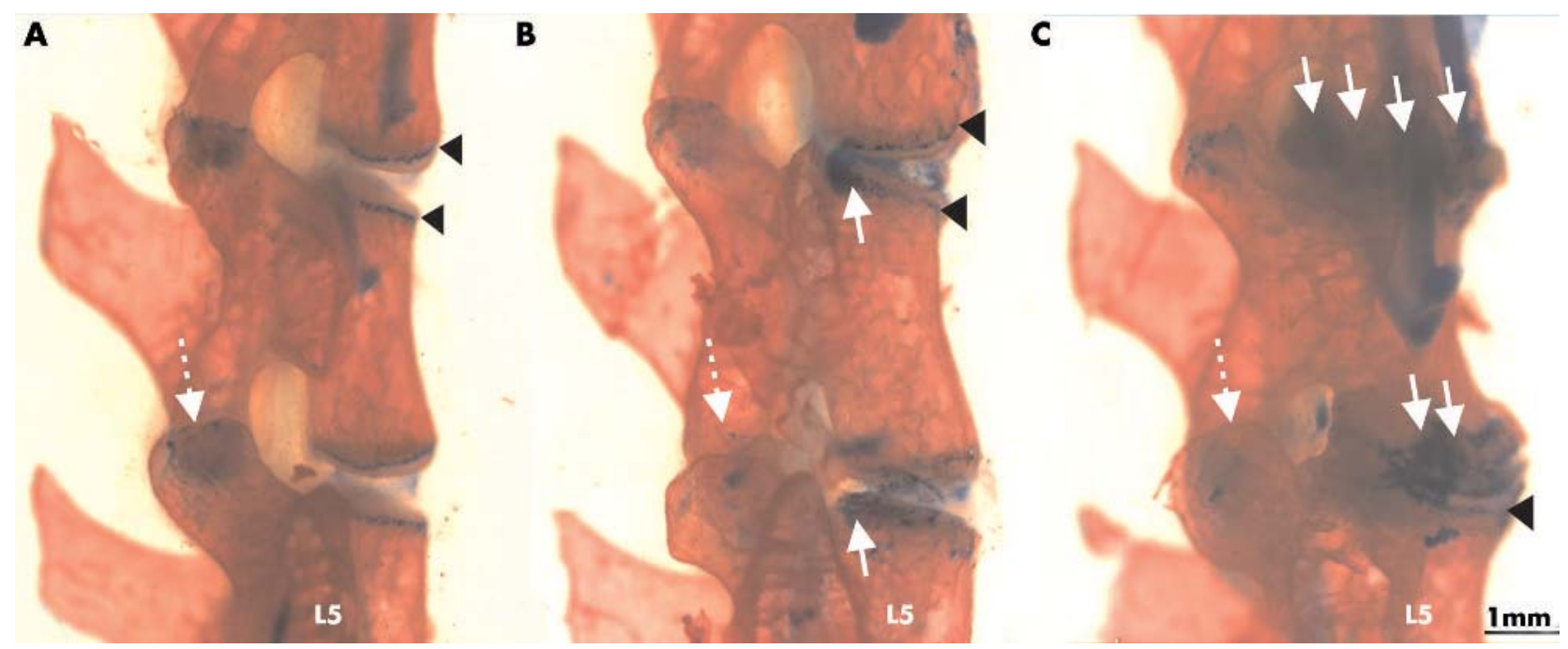

Figure 4 Progression of spondylitis in the lumbar spine (L3-5) in PG immunised BALB/c mice. Alizarin red stains bone red, while alcian blue stains the cartilaginous structures blue. Black arrowheads indicate the cartilaginous growth plates of the vertebral bodies $(A$; control), which became moderately deformed by 12 weeks (B) and grossly altered by 24 weeks (C) after the onset of peripheral joint inflammation. White arrows show chondrophyte formation at the marginal regions of the vertebral bodies.

in PGIA..$^{28-30} 34$ As HLA-B27 transgenic animals, when maintained in germ-free conditions, do not develop spondylitis, ${ }^{25}{ }^{53}$ the molecular mimicry of bacterial antigens may be a strong contributing factor to the pathomechanisms of SpA either in these transgenic rodents or in human patients. Nevertheless, none of these animal models is identical with human AS, but may mimic genetic and/or pathological abnormalities present in the human disease. One example is that, in addition to the major histocompatibility complexes, the major genetic loci of the PGISp in F2 hybrids of BALB/C and $\mathrm{DBA} / 2$, and $\mathrm{BALB} / \mathrm{C}$ and $\mathrm{C} 3 \mathrm{H}$ intercrosses are localised on chromosome 2 (authors unpublished observation), which corresponds with that identified in patients with AS. ${ }^{54}$ PGIA is characterised by a fine cooperation between antibody producing and antigen presenting $\mathrm{B}$ cells and $\mathrm{T}$ helper cells, ${ }^{30} 55$ and affects both the axial and peripheral skeleton.
The chronology of pathological events in this model suggests that the involvement of the sacroiliac joint and the spine is similar to AS. PG immunised mice first exhibit strong mononuclear influx and develop pannus-like tissue in the sacroiliac joint. The infiltrated tissue gradually destroys cartilage, which is followed by complete ankylosis of the joint. Simultaneously with, or shortly after, the initial signs of sacroiliitis, spondylitis/spondylodiscitis flares up with mononuclear infiltration around the annulus, followed by destabilisation of the annulus and protrusion of the nucleus. Matrix components from the nucleus could be additional local sources of autoantigens. The abundance of antigens in this environment can initiate self sustaining (auto)immune reactions that ultimately lead to the complete loss of IVD, and reactive chondrophyte/osteophyte formation and ankylosis, fusing together vertebral bodies.
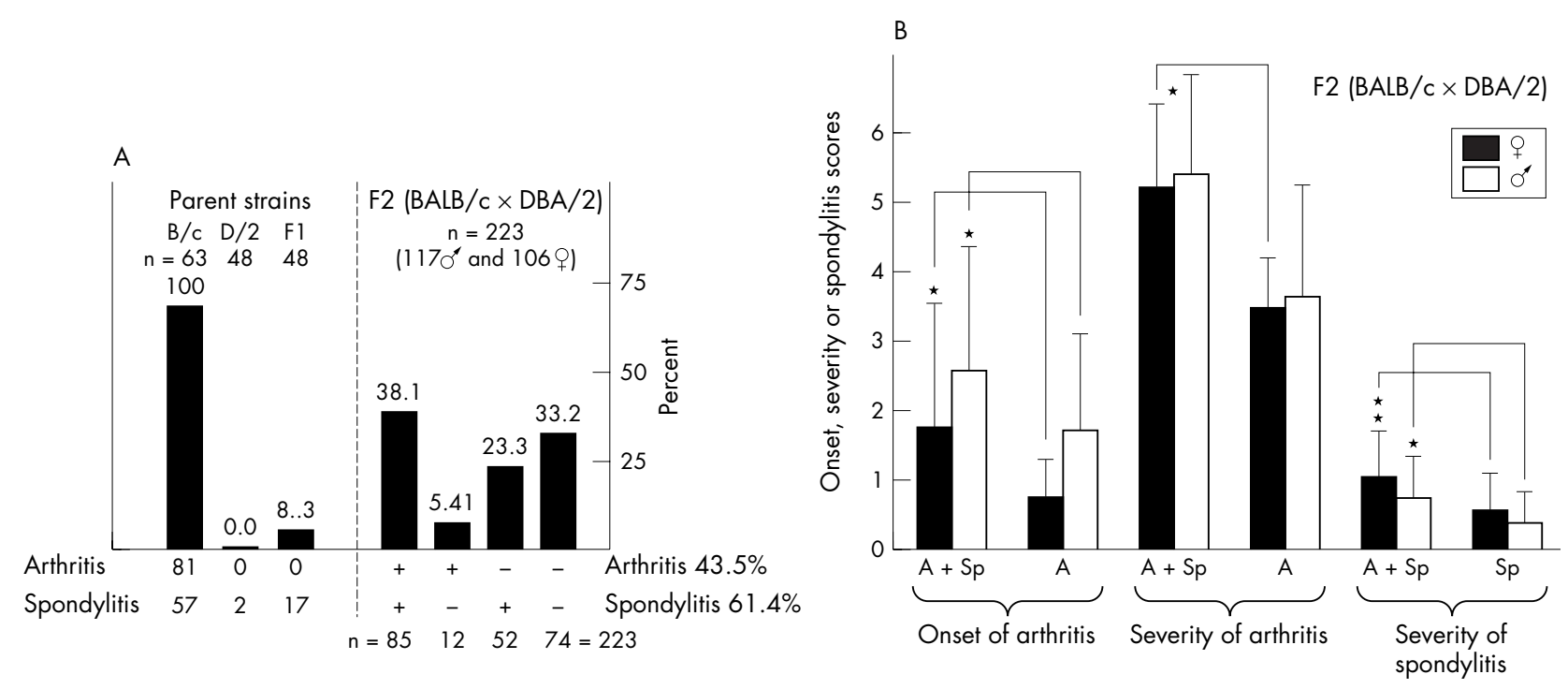

Figure 5 (A) Analysis and comparison of PG-induced arthritis (PGIA: A) and PG-induced spondylitis (PGISp: Sp) in 81 BALB/c (B/C), 48 DBA/2 (D/ 2) mice and their F1 and F2 hybrids (BALB/c $\times D B A / 2)$ immunised with human cartilage PG. All mice were injected four times with PG and killed on week 30 of the experiment-that is, 21 weeks after the last immunisation. (B) Significant differences when male mice and female mice with arthritis or spondylitis, or both, were compared: ${ }^{*} \mathrm{p}<0.05 ;{ }^{* *} \mathrm{p}<0.01$. 
PG is one of the major extracellular matrix proteins located in immunoprivileged sites of the body (such as in the articular cartilage or nucleus pulposus of the IVD), therefore, it might become a target antigen in autoimmune diseases. ${ }^{15-17} 19$ 56-58 Here, we demonstrate that spondylitis develops in arthritis susceptible mice immunised with PG, and the progression of the spine disease resembles that seen in human AS. Therefore, we postulate that PG has an important role in PGISp in this model, and perhaps also has a role in humans with autoimmune SpA..$^{16} 1819$ As far as we know, this is the first time that a systematic and longitudinal study has been performed on spine disease in mice with systemic immunisation with an autoantigen (cartilage PG). We found that spondylitis developed without arthritis, especially in PG immunised F2 hybrids of PGIA susceptible $\mathrm{BALB} / \mathrm{C}$ and resistant DBA/2 strains. Vice versa, about $30 \%$ of arthritic mice did not show evidence of spondylitis. These observations strongly suggest that PGIA and PGISp are independent diseases, although immunisation with cartilage $P G$ is an absolute requirement for the induction of either PGIA or PGISp.

In conclusion, it is very likely that there are both overlapping/shared and distinct genetic components of the (auto)immune regulation in these two models. Although the autoimmune pathomechanisms of PGIA and PGISp seem to be similar, the incidence, severity, and particularly the genetic control of joint and spine involvement are likely to be distinct. Using F2 hybrids of arthritis and spondylitis resistant DBA/2 and susceptible BALB/C mice, we showed a maximum of 57\% (85/149 affected animals) overlap between PGIA and PGISp, whereas $40 \%$ of the F2 hybrid mice with spondylitis did not have arthritis. Therefore, this report supports the relevance of performing genome-wide screening studies for identification of susceptibility loci controlling AS in this experimental murine model, which seems to mimic the human disease.

\section{ACKNOWLEDGEMENTS}

This work was supported, in part, by grants (AR40310, AR45652, AR51163) from the National Institute of Health (USA).

\section{Authors' affiliations \\ T Bárdos, Z Szabó, M Czipri, C Vermes, M Tunyogi-Csapó, R M Urban, \\ K Mikecz, T T Glant, Section of Molecular Medicine, Department of \\ Orthopedic Surgery, Rush University Medical Center, Chicago, IL, USA \\ T Bárdos, M Czipri, C Vermes, M Tunyogi-Csapó, Department of \\ Orthopaedic Surgery, University of Pécs, Pécs, Hungary \\ Z Szabó, Department of Internal Medicine 3, University of Debrecen, \\ Hungary \\ K Mikecz, T T Glant, Department of Biochemistry, Rush University \\ Medical Center, Chicago, IL 60612, USA \\ K Mikecz, Immunology/Microbiology, Rush University Medical Center, Chicago, IL 60612, USA \\ T T Glant, Internal Medicine (Section of Rheumatology), Rush University Medical Center, Chicago, IL 60612, USA}

\section{REFERENCES}

1 Schlosstein L, Terasaki PI, Bluestone R, Pearson CM. High association of an $\mathrm{HL}-\mathrm{A}$ antigen, W27, with ankylosing spondylitis. N Engl J Med 1973;288:704-6

2 Robinson WP, van der Linden SM, Khan MA, Rentsch HU, Cats A, Russell A et al. HLA-Bw60 increases susceptibility to ankylosing spondylitis in HLA-B27+ patients. Arthritis Rheum 1989;32:1135-41.

3 Said-Nahal R, Miceli-Richard C, Berthelot JM, Duche A, Dernis-Labous E, Le Blevec $G$, et al. The familial form of spondylarthropathy: a clinical study of 115 multiplex families. Groupe Francais d'Etude Genetique des Spondylarthropathies. Arthritis Rheum 2000;43:1356-65.

4 Brown MA, Pile KD, Kennedy LG, Campbell D, Andrew L, March R, et al. A genome-wide screen for susceptibility loci in ankylosing spondylitis. Arthritis Rheum 1998:41:588-95.

5 Laval SH, Timms A, Edwards S, Bradbury L, Brophy S, Milicic A, et al. Wholegenome screening in ankylosing spondylitis: evidence of non-MHC geneticsusceptibility loci. Am J Hum Genet 2001;68:918-26.
6 Ebringer RW, Cawdell DR, Cowling P, Ebringer A. Sequential studies in ankylosing spondylitis. Association of Klebsiella pneumoniae with active disease. Ann Rheum Dis 1978;37:146-51.

7 Hermann E, Sucké B, Droste U, Zum Büschenfelde K-HM. Klebsiella pneumoniae-reactive T cells in blood and synovial fluid of patients with ankylosing spondylitis. Arthritis Rheum 1995;38:1277-82.

8 Cancino-Diaz M, Curiel-Quesada E, Garcia-Latorre E, Jimenez-Zamudio L. Cloning and sequencing of the gene that codes for the Klebsiella pneumoniae GroEL-like protein associated with ankylosing spondylitis. Microb Pathog 1998;25:23-32.

9 Ebringer A, Wilson C. HLA molecules, bacteria and autoimmunity. J Med Microbiol 2000:49:305-11.

10 Nickerson CL, Hogen KL, Luthra HS, David CS. Effect of H-2 genes on expression of HLA-B27 and Yersinia-induced arthritis. Scand J Rheumatol 1990;87:85-90.

11 Ugrinovic S, Mertz A, Wu P, Braun J, Sieper J. A single nonamer from the Yersinia $60-\mathrm{kDa}$ heat shock protein is the target of HLA-B27-restricted CTL response in Yersinia-induced reactive arthritis. $J$ Immunol 1997; 159:5715-23.

12 Yu D, Kuipers JG. Role of bacteria and HLA-B27 in the pathogenesis of reactive arthritis. Rheum Dis Clin North Am. 2003;29: 21-36, v-vi).

13 Schwimmbeck PL, Yu DTY, Oldstone MBA. Autoantibodies to HLA B27 in the sera of HLA B27 patients with ankylosing spondylitis and Reiter's syndrome. J Exp Med 1987;166:173-81.

14 Gonzalez-Roces S, Alvarez MV, Gonzalez S, Dieye A, Makni H, Woodfield DG, et al. HLA-B27 polymorphism and worldwide susceptibility to ankylosing spondylitis. Tissue Antigens 1997;49:116-23.

15 Glant T, Csongor J, Szücs T. Immunopathologic role of proteoglycan antigens in rheumatoid joint diseases. Scand J Immunol 1980;11:247-52.

16 Golds EE, Stephen IBM, Esdaile JM, Strawczynski H, Poole AR. Lymphocyte transformation to connective tissue antigens in adult and juvenile rheumatoid arthritis, osteoarthritis, ankylosing spondylitis, systemic lupus erythematosus and a non-arthritic control population. Cell Immunol 1983;82:196-209.

17 Mikecz K, Glant TT, Baron M, Poole AR. Isolation of proteoglycan specific Tcells from patients with ankylosing spondylitis. Cell Immunol $1988 ; 112 \cdot 55-63$

18 Jobanputra P, Choy EHS, Kingsley GH, Sieper J, Palacios-Boix AA, Heinegård D, et al. Cellular immunity to cartilage proteoglycans: relevance to the pathogenesis of ankylosing spondylitis. Ann Rheum Dis 1992;51:959-62.

19 Zou J, Zhang Y, Thiel A, Rudwaleit M, Shi SL, Radbruch A, et al. Predominant cellular immune response to the cartilage autoantigenic $G 1$ aggrecan in ankylosing spondylitis and rheumatoid arthritis. Rheumatology (Oxford) 2003;42:846-55

20 Lipson SJ, Muir H. Vertebral osteophyte formation in experimental disc degeneration. Morphologic and proteoglycan changes over time. Arthritis Rheum 1980;23:319-24.

21 Mahowald ML, Krug H, Taurog J. Progressive ankylosis in mice. An animal model of spondylarthropathy. I. Clinical and radiographic findings. Arthritis Rheum 1988:31:1390-9.

22 Moskowitz RW, Ziv I, Denko CW, Boja B, Jones PK, Adler JH. Spondylosis in sand rats: a model of intervertebral disc degeneration and hyperostosis. J Orthop Res 1990;8:401-11.

23 Hammer RE, Maika SD, Richardson JA, Tang JP, Taurog JD. Spontaneous inflammatory disease in transgenic rats expressing HLA-B27 and human $\beta_{2} \mathrm{~m}$ : an animal model of HLA-B27-associated human disorders. Cell 1990:63:1099-112.

24 Miyamoto S, Yonenobu K, Ono K. Experimental cervical spondylosis in the mouse. Spine 1991;16:S495-500.

25 Khare SD, Luthra HS, David CS. Spontaneous inflammatory arthritis in HLAB27 transgenic mice lacking $\beta_{2}$-microglobulin: a model of human spondyloarthropathies. J Exp Med 1995;182:1153-8.

26 Ho AM, Johnson MD, Kingsley DM. Role of the mouse ank gene in control of tissue calcification and arthritis. Science 2000;289:265-70.

27 Harmey D, Hessle L, Narisawa S, Johnson KA, Terkeltaub R, Millan JL. Concerted regulation of inorganic pyrophosphate and osteopontin by akp2 enppl, and ank: an integrated model of the pathogenesis of mineralization disorders. Am J Pathol 2004; 164:1199-209.

28 Glant TT, Mikecz K, Arzoumanian A, Poole AR. Proteoglycan-induced arthritis in BALB/c mice. Clinical features and histopathology. Arthritis Rheum 1987;30:201-12

29 Glant T, Bárdos T, Vermes C, Chandrasekaran R, Valdéz JC, Otto JM, et al. Variations in susceptibility to proteoglycan-induced arthritis and spondylitis among $\mathrm{C} 3 \mathrm{H}$ substrains of mice. Evidence of genetically acquired resistance to autoimmune disease. Arthritis Rheum 2001;44:682-92.

30 Glant T, Finnegan A, Mikecz K. Proteoglycan-induced arthritis: immune regulation, cellular mechanisms and genetics. Crit Rev Immunol 2003;23:199-250.

31 Shi S, Ciurli C, Cartman A, Pidoux I, Poole AR, Zhang Y. Experimental immunity to the G1 domain of the proteoglycan versican induces spondylitis and sacroiliitis, of a kind seen in human spondylarthropathies. Arthritis Rheum 2003:48:2903-15.

32 Zhang Y. Animal models of inflammatory spinal and sacroiliac joint diseases. Rheum Dis Clin North Am 2003;29:631-45.

33 Mikecz K, Glant TT, Poole AR. Immunity to cartilage proteoglycans in BALB/c mice with progressive polyarthritis and ankylosing spondylitis induced by injection of human cartilage proteoglycan. Arthritis Rheum 1987;30:306-18.

34 Glant T, Cs-Szabó G, Nagase H, Jacobs JJ, Mikecz K. Progressive polyarthritis induced in BALB/c mice by aggrecan from human osteoarthritic cartilage. Arthritis Rheum 1998:41:1007-18. 
35 Glant T, Mikecz K. Proteoglycan aggrecan-induced arthritis: a murine autoimmune model of rheumatoid arthritis. Methods Mol Med 2004; 102:313-38

36 Otto JM, Cs-Szabó G, Gallagher J, Velins S, Mikecz K, Buzás El, et al. Identification of multiple loci linked to inflammation and autoantibody production by a genome scan of a murine model of rheumatoid arthritis. Arthritis Rheum 1999;42:2524-31.

37 Bárdos T, Kamath RV, Mikecz K, Glant TT. Anti-inflammatory and chondroprotective effect of TSG- 6 (tumor necrosis factor- $\alpha$-stimulated gene-6) in murine models of experimental arthritis. Am J Pathol 2001;159:1711-21.

38 Czipri M, Otto JM, Cs-Szabó G, Kamath RV, Vermes C, Firneisz G, et al. Genetic rescue of chondrodysplasia and the perinatal lethal effect of cartilage link protein deficiency. J Biol Chem 2003;278:39214-23.

39 Kimmel CA, Trammell C. A rapid procedure for routine double staining of cartilage and bone in fetal and adult animals. Stain Technol 1981;56:271-3

40 Bárdos T, Mikecz K, Finnegan A, Zhang J, Glant TT. T and B cell recovery in arthritis adoptively transferred to SCID mice: antigen-specific activation is required for restoration of autopathogenic CD4+ Th1 cells in a syngeneic system. J Immunol 2002;168:6013-21.

41 Schmidt MB, Mow VC, Chun LE, Eyre DR. Effects of proteoglycan extraction on the tensile behavior of articular cartilage. J Orthop Res 1990;8:353-63.

42 Waggett AD, Ralphs JR, Kwan AP, Woodnutt D, Benjamin M. Characterization of collagens and proteoglycans at the insertion of the human Achilles tendon. Matrix Biol 1998;16:457-70.

43 Pearce RH, Grimmer BJ, Adams ME. Degeneration and the chemical composition of the human lumbar intervertebral disc. J Orthop Res 1987;5:198-205.

44 Kang JD, Stefanovic-Racic M, McIntyre LA, Georgescu HI, Evans CH. Toward a biochemical understanding of human intervertebral disc degeneration and herniation. Contributions of nitric oxide, interleukins, prostaglandin E2, and matrix metalloproteinases. Spine 1997;22:1065-73.

45 Szanto S, Bárdos T, Szabo Z, David CS, Buzás E, Mikecz K, et al. Induction of arthritis in HLA-DR4-humanized and HLA-DQ8-humanized mice by human cartilage proteoglycan aggrecan but only in the presence of an appropriate (non-MHC) genetic background. Arthritis Rheum 2004;50:1984-95.

46 Doege KJ, Sasaki M, Kimura T, Yamada Y. Complete coding sequence and deduced primary structure of the human cartilage large aggregating proteoglycan, aggrecan. Human- specific repeats, and additional alternativley spliced forms. J Biol Chem 1991;266:894-902.

47 Walcz E, Deák F, Erhardt P, Coulter SN, Fülöp C, Horváth P, et al. Complete coding sequence, deduced primary structure, chromosomal localization and structural analysis of murine aggrecan. Genomics 1994;22:364-71.

48 Kabasakal Y, Garrett SL, Calin A. The epidemiology of spondylodiscitis in ankylosing spondylitis-a controlled study. Br J Rheumatol 1996;35:660-3.

49 Braun J, Bollow M, Sieper J. Radiologic diagnosis and pathology of the spondyloarthropathies. Rheum Dis Clin North Am 1998:24:697-735.

50 Eulderink F. Pathology of ankylosing spondylitis. Spine State of the Art Reviews 1990;4:507-28.

51 Fry TR, Eurell JC, Johnson AL, Brown MD, Losonsky JM, Schaeffer DJ. Radiographic and histologic effects of chondroitinase $A B C$ on normal canine lumbar intervertebral disc. Spine 1991;16:816-19.

52 Taurog JD, Maika SD, Satumtira N, Dorris ML, McLean IL, Yanagisawa H, et al. Inflammatory disease in HLA-B27 transgenic rats. Immunol Rev 1999; 169:209-23

53 Taurog JD, Richardson JA, Croft JT, Simmons WA, Zhou M, FernandezSueiro JL, et al. The germfree state prevents development of gut and joint inflammatory disease in HLA-B27 transgenic rats. J Exp Med 1994; 180:2359-64.

54 Brown MA, Brophy S, Bradbury L, Hamersma J, Timms A, Laval S, et al. Identification of major loci controlling clinical manifestations of ankylosing spondylitis. Arthritis Rheum 2003;48:2234-9.

55 Glant TT, Mikecz K, Thonar EJMA, Kuettner KE. Immune responses to cartilage proteoglycans in inflammatory animal models and human diseases. In: Woessner JF, Howell DS, eds. Cartilage degradation: basic and clinical aspects. New York: Marcel Dekker, 1992:435-73.

56 Karopoulos C, Rowley MJ, llic MZ, Handley CJ. Presence of antibodies to native Gl domain of aggrecan core protein in synovial fluids from patients with various joint diseases. Arthritis Rheum 1996;39:1990-7.

57 Guerassimov A, Zhang YP, Baneriee S, Cartman A, Leroux JY, Rosenberg LC, et al. Cellular immunity to the $\mathrm{Gl}$ domain of cartilage proteoglycan aggrecan is enhanced in patients with rheumatoid arthritis but only after removal of keratan sulfate. Arthritis Rheum 1998;41:1019-25.

58 Li NL, Zhang DQ, Zhou KY, Cartman A, Leroux JY, Poole AR, et al. Isolation and characteristics of autoreactive $T$ cells specific to aggrecan $G 1$ domain from rheumatoid arthritis patients. Cell Res 2000;10:39-49. 